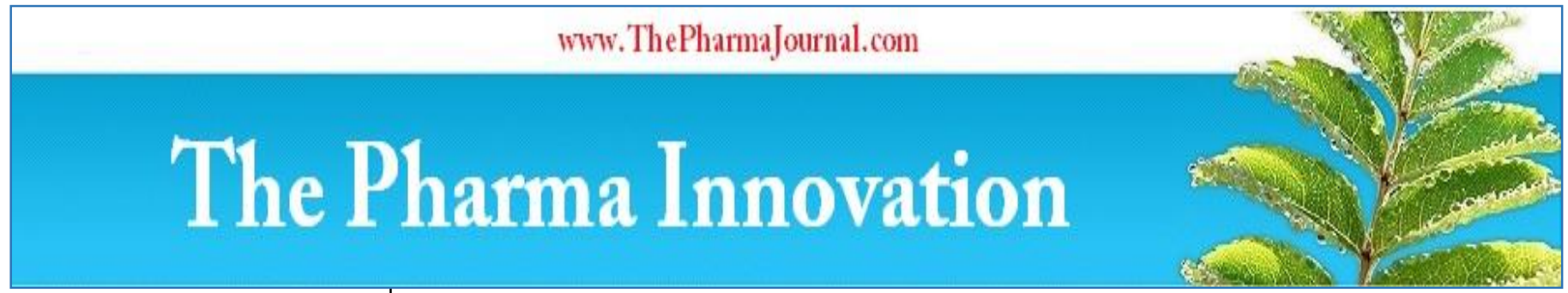

ISSN (E): 2277 - 7695

ISSN (P): 2349-8242

NAAS Rating: 5.23

TPI 2021; 10(4): 160-165

(C) $2021 \mathrm{TPI}$

www.thepharmajournal.com

Received: 08-02-2021

Accepted: 15-03-2021

\section{Vandana Bhakuni}

Department of Seed Science and Technology, GBPUA\&T, Hill

Campus, Ranichauri, Tehri

Garhwal, Uttarakhand, India

\section{Rajendra Prasad}

Department of Seed Science and Technology, GBPUA\&T, Hill Campus, Ranichauri, Tehri

Garhwal, Uttarakhand, India

\section{Prabha Shankar Shukla}

Department of Seed Science and

Technology, GBPUA\&T, Hill

Campus, Ranichauri, Tehri

Garhwal, Uttarakhand, India
Corresponding Author: Vandana Bhakuni

Department of Seed Science and Technology, GBPUA\&T, Hill

Campus, Ranichauri, Tehri

Garhwal, Uttarakhand, India

\section{Genetic variability and correlation studies for morphological and seed quality parameters in foxtail millet (Setaria italic (L.) Beauv.)}

\author{
Vandana Bhakuni, Rajendra Prasad and Prabha Shankar Shukla
}

DOI: $\underline{\text { https://doi.org/10.22271/tpi.2021.v10.i4c.5911 }}$

\begin{abstract}
Foxtail millet (Setaria italica (L.) Beauv.) is one of the world's oldest cultivated crops. It's domestication and cultivation is estimated to have occurred over 4000 years ago (Chang, 1968). By virtue of it's composition it is quite comparable to Rice and Wheat in it's nutritive value. It has got fairly high proportion of crude protein $(8.2 \%)$, minerals $(6.7 \%)$, digestible protein $(4.9 \%)$ and exceptionally higher fibre contents $(25.3 \%)$. But, in India, the potentiality of foxtail millet is not yet exploited properly. Hence, the present investigation was conducted with 46 genotypes of Foxtail millet with an objective to study the genetic variability and correlation for morphological as well as seed quality parameters. Twenty-three characters were examined in the field for morphological and yield contributing traits while twelve parameters were examined in the laboratory for seed quality. The analysis of variance revealed significant variation among different genotypes. Most of the seed quality and field parameters recorded high estimates for broad sense heritability. All of the seed quality parameters exhibited positive genotypic and phenotypic correlation with each other. Based on studies it was concluded that all the genotypes included in the present study are having wide array of variation for different yield contributing traits as well as seed quality parameters. So, these genotypes could be further adopted for breeding improvement.
\end{abstract}

Keywords: Foxtail millet, genetic variability, quality parameters, correlation, heritability

\section{Introduction}

Millet is a general term for a wide range of small seeded cereals (Marcon, 1994) ${ }^{[12]}$. The millets which belong to the family Poaceae (Gramineae) are small seeded annual grasses, including a wide range of cereals that may be used both as grain and for forage (Schery, 1972) [15]. Millets are nutritionally comparable to Rice and Wheat in different nutritional aspects and it provides cheap protein, minerals and vitamins to the population of low economic status, where the need for such ingredients is maximum. According to an estimate, hill farmers consume $80 \%$ millets, $10 \%$ other food grains, $7 \%$ vegetable sand pulses, $2 \%$ milk and $1 \%$ meat which emphasize that millets play a vital role in meeting their nutritional requirements (Joshi \& Katoch, 1990) ${ }^{[9]}$. Foxtail millet is an important minor millet and also is the most economically valuable of the genus. Foxtail millet ranks second in the world's total production of millets and is an important staple food for millions of people in Southern Europe and Asia (Marathee, 1993) ${ }^{[11]}$. The geographical origin of foxtail millet based on cytological studies indicated that a wild ancestor of foxtail millet is $S$. viridis ( $\mathrm{Li}$ et al., 1935) ${ }^{[10]}$. Besides India, it is also grown in China, Russia, Japan, U.S.A. and other African and East Asian countries. Foxtail millet is suited to conditions of low and moderate rainfall area due to early maturity period. Chromosome number of foxtail millet is $9,2 n=18$. Photosynthetic pathway in foxtail millet is C4. Foxtail millet is an annual grass with slim, vertical, leafy stems which can reach a height of 120-200 cm (4-7 ft.). The seedhead is a dense, hairy panicle and 5-30 cm long. The small seeds, around $2 \mathrm{~mm}$ in diameter, are encased in a thin, papery hull which is easily removed after threshing. Seed colour varies greatly between genotypes. Foxtail millet is largely self-pollinated, with cross pollination averaging about $4 \%$ (Li et al., 1935) ${ }^{[10]}$.

In spite of it's nutritive value the cultivation of foxtail millet in India is confined to Andhra Pradesh, Karnataka and Tamil Nadu. The yield levels in India are relatively low suggesting a greater scope for exploitation of this millet under Indian conditions. There is a wide genetic diversity available in foxtail millet. The identification of genotypes with high variability and heritability for morphological and seed quality parameters is the prerequisites of breeding programme. 
Partitioning of variance into various components provides information regarding breeding value and nature and magnitude of variability in the expression of a particular trait. Recognizing this, the present investigation is carried out to gather information on magnitude of genetic variability and correlation in foxtail millet.

\section{Materials and Method}

The field experiment was conducted during kharif 2010 at research block of the Department of Seed Science and Technology, G. B. Pant University of Agriculture and Technology, Hill campus, Ranichauri, Tehri Garhwal, Uttarakhand. Forty-six genotypes of foxtail millet (Setaria italica (L.) Beauv.) Obtained from ICRISAT, Hyderabad together with a check PRK-1(c) was used as the planting material. The evaluation was done to estimate variability in general performance of genotypes for morphological and seed quality parameters. The experiment was laid out in complete randomized block design with two replications. Each genotype was raised in a row having ten plants and the plot size was $3 \times 0.25 \mathrm{~m}$. Seeds were planted at $25 \times 25 \mathrm{~cm}$ distance apart by supplementing with $40 \mathrm{~kg}$ nitrogen, $20 \mathrm{~kg}$ phosphorus and $20 \mathrm{~kg}$ of potash. Data was recorded for different trait on five tagged plants for each replication and was analyzed to study the coefficients of variances, heritability, genetic advance and character correlation. Twenty-three morphological characters were analyzed. After analyzing the morphological characters fifty seeds of each genotype were arranged on wet filter paper in pertiplates for 10 days according to ISTA (2008). The closed petriplates were placed in a germinator at $25+1{ }^{\circ} \mathrm{C}$. The seedlings were evaluated daily and final count was made on $10^{\text {th }}$ day. Twelve parameters were analyzed to study the coefficients of variances, heritability, genetic advance and character correlation.

\section{Results and Discussion}

Variability studies: Genetic variability in forty-six genotypes of foxtail millet during the present investigation has been studied through analysis of variance and coefficient of variation [Table 1(a) \& (b)]. The calculated values of GCV ranged from 4.62 (germination percent) to 113.57 (grain weight per ear), and PCV values ranged from 6.42 also for (germination percent) to 122.88 (grain weight per ear). These results indicated that the material under study provide ample scope for improvement through selection in these characters. The maximum phenotypic variation was recorded for grain weight per ear (122.88). This result was in accordance with Baghel and Maloo, 2002 in proso millet. High magnitude of GCV and PCV was recorded for number of basal tillers (51.27, 61.01 respectively). While moderate magnitude of GCV and PCV was observed for ear length (20.50, 34.82 respectively). Similar findings have also been revealed by John, 2007 in finger millet. The highest magnitude of GCV and PCV were recorded for characters like grain weight per ear followed by grain yield per plant, grain yield per meter, number of seeds on main ear suggesting ample variation for improvement through selection for these characters.

Low estimates of GCV and PCV were recorded for characters like days to $50 \%$ flowering (18.62, 19.58 respectively), germination percent $(4.62,6.42$ respectively), and plant height $(15.68,18.30$ respectively) in different genotypes. These findings are in conformity with the findings of Sonnad, et al., $2008^{[17]}$ in ragi. These findings revealed very less opportunities for selection to improve the population for these traits. Highest magnitudes of GCV and PCV were recorded for germinative energy $(58.90,60.49$ respectively), speed of germination (57.30, 58.75 respectively). Similar results of significant variability for different traits in Indian mustard were reported by Pant and Singh, $2001{ }^{[16]}$. Genotypic differences in seedling vigour and it's components have been reported in many crops. Highest magnitude for GCV and PCV was recorded for vigour index II (81.03, 88.42 resp.) while lowest was recorded for seedling length $(26.80 \&$ 35.15). Moderate estimates of GCV and PCV were recorded for root length, shoot length, seedling fresh weight and 1000 seed weight.

The genetic constants for the characters revealed that the magnitude of phenotypic coefficient of variation (PCV) was higher than the corresponding genotypic coefficient of variation $(\mathrm{GCV})$ for all the traits denoting environmental factors influencing their expression to some extent [Table 1(a) \& (b)]. Wide differences between GCV and PCV implied their susceptibility to environmental fluctuations, whereas narrow differences between GCV and PCV suggested their resistance to environmental alterations. Similar findings have been reported by Jain, et al., $2011^{[7]}$ in forage sorghum. Table $1(\mathrm{a}) \&(\mathrm{~b})$

Table 1(a): Estimation of GCV \& PCV for field parameters of different Genotypes of Foxtail millet

\begin{tabular}{|c|c|c|c|}
\hline S. No. & Parameters & GCV & PCV \\
\hline 1 & Germination percent & 4.62 & 6.42 \\
\hline 2 & Days to 50\% flowering & 18.60 & 19.58 \\
\hline 3 & Plant height (cm) & 15.68 & 18.30 \\
\hline 4 & No. of basal tillers & 51.27 & 61.01 \\
\hline 5 & Girth (mm) & 26.37 & 29.37 \\
\hline 6 & Internodal distance $(\mathrm{cm})$ & 22.32 & 25.25 \\
\hline 7 & No. of leaf on main tiller & 9.49 & 17.14 \\
\hline 8 & Sheath length of flag leaf $(\mathrm{cm})$ & 18.72 & 21.16 \\
\hline 9 & Plant leaf length $(\mathrm{cm})$ & 20.63 & 25.82 \\
\hline 10 & Flag leaf width $(\mathrm{cm})$ & 9.92 & 19.61 \\
\hline 11 & Peduncle length $(\mathrm{cm})$ & 27.22 & 29.43 \\
\hline 12 & Peduncle exsertion $(\mathrm{cm})$ & 72.21 & 80.09 \\
\hline 13 & No. of ears per plant & 42.01 & 57.46 \\
\hline 14 & Ear length $(\mathrm{cm})$ & 20.50 & 34.82 \\
\hline 15 & No. of finger per ear & 33.37 & 36.98 \\
\hline 16 & Finger length (mm) & 39.36 & 41.57 \\
\hline 17 & Finger width (mm) & 42.55 & 44.18 \\
\hline 18 & Bristle length $(\mathrm{cm})$ & 34.98 & 37.12 \\
\hline 19 & No. of seeds on main ear & 77.98 & 89.08 \\
\hline 20 & 1000 grain weight $(\mathrm{g})$ & 48.78 & 50.23 \\
\hline 21 & Grain weight per ear $(\mathrm{g})$ & 113.57 & 122.88 \\
\hline 22 & Grain yield per plant $(\mathrm{g})$ & 97.45 & 105.19 \\
\hline 23 & Grain yield per meter $(\mathrm{g})$ & 97.46 & 105.18 \\
\hline
\end{tabular}

Table 1(b): Estimation of GCV \& PCV for seed quality parameters in different Genotypes of Foxtail millet

\begin{tabular}{|c|c|c|c|}
\hline S. No. & Parameters & GCV & PCV \\
\hline 1 & Standard germination percent & 56.46 & 57.91 \\
\hline 2 & Germinative energy & 58.90 & 60.49 \\
\hline 3 & Mean daily germination & 56.46 & 57.91 \\
\hline 4 & Speed of germination & 57.30 & 58.75 \\
\hline 5 & Root length $(\mathrm{cm})$ & 31.66 & 40.25 \\
\hline 6 & Shoot length $(\mathrm{cm})$ & 33.09 & 42.66 \\
\hline 7 & Seedling length $(\mathrm{cm})$ & 26.80 & 35.15 \\
\hline 8 & Seedling fresh weight $(\mathrm{g})$ & 39.08 & 45.01 \\
\hline 9 & Seedling dry weight $(\mathrm{g})$ & 53.72 & 61.95 \\
\hline 10 & 1000 seed weight $(\mathrm{g})$ & 49.03 & 49.86 \\
\hline 11 & Vigour index II & 81.03 & 88.42 \\
\hline 12 & Vigour index I & 65.11 & 68.64 \\
\hline
\end{tabular}


Heritability and genetic advance: With the help of GCV and PCV alone, it is not possible to determine the amount of variation. Thus, the heritability estimates along with genetic advance is meaningful. The estimates of heritability in present investigation were of higher magnitudes $(>50 \%)$ for all the characters studied [Table 2(a) \& (b)]. Analysis of data registered high heritability for 1000 grain weight $(\mathrm{g})$. The characters such as days to $50 \%$ flowering, finger width (mm) and 1000 grain weight (g) showed more than $90 \%$ heritability. For the characters showing high heritability, the selection of superior genotypes on the basis of phenotypic performance will be effective. Highest estimates for genetic advance were recorded for number of seeds on main ear followed by grain yield per meter. Flag leaf width, number of ears per plant, finger width, bristle length and 1000 grain weight exhibited comparatively low genetic advance [Table 2(a)]. The characters which exhibited estimates of heritability between 60 to $80 \%$ were flag leaf length $(63 \%)$, number of basal tillers $(70 \%)$, plant height $(73 \%)$, number of seeds on main ear $(76 \%)$, sheath length of flag leaf and intermodal distance $(78 \%)$. The broad sense heritability (\%) estimates were of higher magnitude for standard germination percent, germinative energy, mean daily germination, speed of germination and 1000 seed weight. Whereas moderate values were recorded for vigour index, seedling fresh weight and dry weight.

Seedling fresh weight, seedling dry weight, root length and shoot length exhibited comparatively low genetic advance while standard germination percent, germinative energy exhibited moderate genetic advance [Table 2(b)]. High value for genetic advance was exhibited by vigour index II. In the present investigation moderately higher expected genetic advance for seed quality parameters were recorded for all the characters which indicate scope for improvement in the genotypes.

In the present investigation moderate expected genetic advance for field parameters were recorded for all the characters indicating scope for their improvement. Grain weight per ear exhibiting high GCV and PCV accompanied by high heritability estimates accompanied by low genetic advance was observed in most of the characters. It may be inferred that these characters were conditioned by nonadditive gene action and simple selection would not be rewarding directly for improvement. Table 2(a) \& (b)

Table 2(a): Estimation of heritability and genetic advance for field parameters in different Genotypes of Foxtail millet

\begin{tabular}{|c|c|c|c|}
\hline S. No. & Parameters & $\mathbf{H}^{\mathbf{2} \%}$ & GA \\
\hline 1 & Germination percent & 0.51 & 6.07 \\
\hline 2 & Days to 50\% flowering & 0.90 & 8.35 \\
\hline 3 & Plant height $(\mathrm{cm})$ & 0.73 & 36.39 \\
\hline 4 & No. of basal tillers & 0.70 & 3.59 \\
\hline 5 & Girth (mm) & 0.80 & 2.56 \\
\hline 6 & Internodal distance $(\mathrm{cm})$ & 0.78 & 3.34 \\
\hline 7 & No. of leaf on main tiller & 0.32 & 1.14 \\
\hline 8 & Sheath length of flag leaf $(\mathrm{cm})$ & 0.78 & 4.34 \\
\hline 9 & Plant leaf length $(\mathrm{cm})$ & 0.63 & 8.27 \\
\hline 10 & Flag leaf width $(\mathrm{cm})$ & 0.25 & 0.25 \\
\hline 11 & Peduncle length $(\mathrm{cm})$ & 0.85 & 9.65 \\
\hline 12 & Peduncle exsertion $(\mathrm{cm})$ & 0.81 & 7.94 \\
\hline 13 & No. of ears per plant & 0.53 & 2.80 \\
\hline 14 & Ear length (cm) & 0.34 & 3.14 \\
\hline 15 & No. of finger per ear & 0.81 & 30.97 \\
\hline 16 & Finger length $(\mathrm{mm})$ & 0.89 & 6.41 \\
\hline 17 & Finger width $(\mathrm{mm})$ & 0.92 & 3.87 \\
\hline 18 & Bristle length $(\mathrm{cm})$ & 0.88 & 0.45 \\
\hline 19 & No. of seeds on main ear & 0.76 & 1623.24 \\
\hline 20 & 1000 grain weight $(\mathrm{g})$ & 0.94 & 4.04 \\
\hline 21 & Grain weight per ear $(\mathrm{g})$ & 0.85 & 7.43 \\
\hline 22 & Grain yield per plant $(\mathrm{g})$ & 0.85 & 9.62 \\
\hline 23 & Grain yield per meter $(\mathrm{g})$ & 0.85 & 96.27 \\
\hline
\end{tabular}

Table 2(b): Estimation of heritability and genetic advance for seed quality parameters in different genotypes of Foxtail millet

\begin{tabular}{|c|c|c|c|}
\hline S. No. & Parameters & $\mathbf{H}^{\mathbf{2 \%}}$ & GA \\
\hline 1 & Standard germination percent & 0.95 & 67.01 \\
\hline 2 & Germinative energy & 0.94 & 66.14 \\
\hline 3 & Mean daily germination & 0.95 & 6.70 \\
\hline 4 & Speed of germination & 0.95 & 6.67 \\
\hline 5 & Root length $(\mathrm{cm})$ & 0.61 & 2.31 \\
\hline 6 & Shoot length $(\mathrm{cm})$ & 0.60 & 2.81 \\
\hline 7 & Seedling length $(\mathrm{cm})$ & 0.58 & 4.14 \\
\hline 8 & Seedling fresh weight $(\mathrm{g})$ & 0.75 & 0.03 \\
\hline 9 & Seedling dry weight $(\mathrm{g})$ & 0.75 & 0.003 \\
\hline 10 & 1000 seed weight $(\mathrm{g})$ & 0.96 & 4.09 \\
\hline 11 & Vigour index II & 0.83 & 0.40 \\
\hline 12 & Vigour index I & 0.89 & 769.29 \\
\hline
\end{tabular}

Phenotypic and genotypic association: Pooled analysis for the correlation coefficients among the various traits revealed that days to $50 \%$ flowering showed significant positive correlation with plant height. This finding is lined with the findings of Giriraj and Goud, 1981 ${ }^{[3]}$ in grain sorghum. Ear length exhibited positively high significant genotypic correlation with number of fingers per ear, finger length, finger width, number of seeds on main ear, 1000 grain weight, grain weight per ear, grain yield per plant and grain yield per meter [Table 3(a)]. These finding are in conformity with the findings of Singh, et al., $2011^{[16]}$ in mustard.

Grain yield per plant was positively and significantly associated with number of fingers per ear, finger width and number of seeds on main ear while it was negatively correlated with days to $50 \%$ flowering. These results were in accordance with Yadav and Dhankhar, 2001 ${ }^{[18]}$ in okra. Number of seeds on main ear showed a significant positive 
genotypic correlation with grain weight per ear (0.90), grain yield per plant (0.93) and grain yield per m (0.93). It also showed highly significant positive phenotypic correlation with grain weight per ear (0.87), grain yield per plant $(0.84)$ and grain yield per $m(0.84)$. Thereby, it indicated that number of seeds on main ear is a complex character. Germination per cent was positively and significantly associated with plant height. Number of ears per plant was also positively and significantly associated with number of basal tillers. Grain weight per ear was negatively and significantly associated with days to $50 \%$ flowering. Plant height showed significant positive genotypic and phenotypic correlation with number of basal tillers. This result is in accordance with Giriraj and Goud, 1981 ${ }^{[3]}$ in sorghum. The flag leaf length showed significant correlation with number of basal tillers and ear length. This finding is lined with the findings of Giriraj and Goud, $1981^{[3]}$ in sorghum [Table 3 (a)].

In laboratory germination test, standard germination per cent was positively and significantly associated with germination energy, mean daily germination, speed of germination, root length, seedling length, seedling fresh weight, seedling dry weight, vigour index II and vigour index I. Seedling fresh weight exhibited positive and significant association with seedling length and root length [Table 3(b)]. Similar results were revealed by Baghel and Maloo, 2002 in proso millet. Germination per cent exhibited significant and positive correlation with germinative energy, root length, seedling length and vigour index I. This result is accompanied by Patil, $2007^{[14]}$ in finger millet. Vigour index II showed a highly significant and positive genotypic as well as phenotypic correlation (0.70) and (0.63) respectively with vigour index I. Highly significant and positive association of vigour index I was reported with germination per cent, root length, shoot length and seedling length in different genotypes which are some of it's determining characters. Similar observations were accompanied by Patil, $2007^{[14]}$ in proso millet [Table 3(b)]. Table 3(a) \& (b)

Association between some characters was non-significant which implies that the two variables are not linearly related. Similar findings were revealed by Gomez and Gomez, 1980

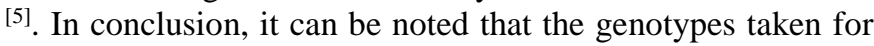
study had wide range of variance for morphological and seed quality parameters, so there is more scope for improvement of these characters. Yield contributing traits should be improved through simple selection procedure for these traits.

Table 3 (a): Genotypic and phenotypic correlation between filed parameters in different Genotypes of Foxtail millet

\begin{tabular}{|c|c|c|c|c|c|c|c|c|c|c|c|c|c|c|c|c|}
\hline Characters & & $\begin{array}{c}\text { Germinat } \\
\text { ion } \%\end{array}$ & \begin{tabular}{|c|} 
Days to \\
$\mathbf{5 0 \%}$ \\
flowering \\
\end{tabular} & \begin{tabular}{|c|} 
Plant \\
height
\end{tabular} & $\begin{array}{l}\text { No. of } \\
\text { basal } \\
\text { tillers } \\
\end{array}$ & \begin{tabular}{|c|}
$\begin{array}{c}\text { Flag } \\
\text { leaf } \\
\text { length }\end{array}$ \\
\end{tabular} & $\begin{array}{c}\text { No. of } \\
\text { ears/ } \\
\text { plant }\end{array}$ & \begin{tabular}{|c|} 
Ear \\
length
\end{tabular} & \begin{tabular}{|c|}
$\begin{array}{c}\text { No. of } \\
\text { fingers/ } \\
\text { ear }\end{array}$ \\
\end{tabular} & $\begin{array}{l}\text { Finger } \\
\text { length }\end{array}$ & $\begin{array}{c}\text { Finger } \\
\text { width }\end{array}$ & \begin{tabular}{|c|}
$\begin{array}{c}\text { No. of } \\
\text { seeds on } \\
\text { main ear }\end{array}$ \\
\end{tabular} & \begin{tabular}{|c|}
$\begin{array}{c}1000 \\
\text { grain } \\
\text { wt. }\end{array}$ \\
\end{tabular} & $\begin{array}{c}\text { Grain } \\
\text { wt./ear }\end{array}$ & $\begin{array}{c}\text { Grain } \\
\text { yield/plant }\end{array}$ & \begin{tabular}{|l|} 
Grain \\
yield/ \\
metre \\
\end{tabular} \\
\hline & & 1 & 2 & 3 & 4 & 5 & 6 & 7 & 8 & 9 & 10 & 11 & 12 & 13 & 14 & 15 \\
\hline \multirow{2}{*}{$\begin{array}{c}\text { Germinatio } \\
\text { n } \%\end{array}$} & G & & $0.3199 *$ & $\begin{array}{c}0.7585 * \\
*\end{array}$ & 0.2484 & -0.2707 & $\begin{array}{c}0.3054 \\
*\end{array}$ & 0.1282 & 0.0967 & -0.2254 & $\begin{array}{c}- \\
0.4799 * *\end{array}$ & 0.1716 & -0.2532 & 0.1654 & 0.2402 & 0.2394 \\
\hline & $\mathrm{P}$ & & 0.2248 & \begin{tabular}{|c|}
$0.4176 *$ \\
$*$
\end{tabular} & 0.1423 & -0.1384 & 0.2548 & -0.0370 & 0.0228 & -0.1752 & $\begin{array}{c}- \\
0.3295 * * \\
\end{array}$ & 0.0286 & -0.1812 & 0.0237 & 0.0897 & 0.0902 \\
\hline \multirow{2}{*}{$\begin{array}{c}\text { Days to } \\
50 \% \\
\text { flowering }\end{array}$} & G & & & $\begin{array}{c}0.4442 * \\
*\end{array}$ & $\begin{array}{c}0.5710^{*} \\
*\end{array}$ & -0.0144 & $\begin{array}{c}0.3675 \\
*\end{array}$ & $\mid-0.0982$ & -0.1576 & $-0.4398 * *$ & $0.6739 * *$ & $-0.3530 *$ & $-0.3446 *$ & $\begin{array}{c}0.4493 * \\
*\end{array}$ & $-0.3205^{*}$ & $0 . \overline{-} 206^{*}$ \\
\hline & $\mathrm{P}$ & & & $\begin{array}{c}0.3821 * \\
*\end{array}$ & $\begin{array}{c}0.4554 * \\
*\end{array}$ & -0.0033 & $\begin{array}{c}0.2888 \\
*\end{array}$ & $\mid-0.0702$ & -0.0764 & $-0.4080 * *$ & $\overline{-}-\overline{245 * *}$ & -0.2697 & $-0.3316^{*}$ & $\begin{array}{c}- \\
0.3917 * \\
*\end{array}$ & -0.2672 & -0.2672 \\
\hline \multirow[t]{2}{*}{ Plant height } & $\mathrm{G}$ & & & & $\begin{array}{c}0.4642 * \\
*\end{array}$ & 0.1748 & 0.0855 & 0.1789 & 0.2437 & -0.0411 & -0.1893 & 0.2406 & -0.0768 & 0.1384 & 0.2621 & 0.2621 \\
\hline & $\mathrm{P}$ & & & & $0.3122^{*}$ & 0.1158 & 0.0712 & 0.1972 & 0.2256 & -0.0169 & -0.1617 & 0.1599 & -0.0522 & \begin{tabular}{|l|}
0.1092 \\
\end{tabular} & 0.2286 & 0.2284 \\
\hline \multirow{2}{*}{$\begin{array}{c}\text { No. of basal } \\
\text { tillers }\end{array}$} & G & & & & & 0.1578 & $\begin{array}{c}0.8727 \\
* *\end{array}$ & $\mid-0.1300$ & 0.0055 & $-0.3944 * *$ & $\begin{array}{c}- \\
0.5047 * * \\
\end{array}$ & -0.1851 & -0.0616 & $-0.3245^{*}$ & -0.0760 & -0.0747 \\
\hline & $\mathrm{P}$ & & & & & 0.1568 & $\begin{array}{c}0.6557 \\
* *\end{array}$ & $\mid-0.0056$ & 0.0710 & $-0.3422 *$ & -0.4447 & -0.1414 & -0.0349 & -0.2525 & -0.0409 & -0.0418 \\
\hline \multirow{2}{*}{$\begin{array}{c}\text { Flag leaf } \\
\text { length }\end{array}$} & G & & & & & & 0.0440 & $\begin{array}{c}0.4920 * \\
*\end{array}$ & $\begin{array}{c}0.3121 * \\
*\end{array}$ & $0.3375^{*}$ & 0.2648 & 0.2099 & 0.3122 & 0.2069 & 0.2288 & 0.2290 \\
\hline & $\mathrm{P}$ & & & & & & 0.0673 & \begin{tabular}{|l|}
0.0473 \\
\end{tabular} & \begin{tabular}{|l|}
0.2529 \\
\end{tabular} & 0.2423 & 0.1958 & 0.1484 & 0.2859 & \begin{tabular}{|l|}
0.2034 \\
\end{tabular} & 0.2459 & 0.2450 \\
\hline \multirow{2}{*}{$\begin{array}{c}\text { No. of } \\
\text { ears/plants }\end{array}$} & G & & & & & & & -0.1543 & 0.1756 & $-0.2812 *$ & $\begin{array}{c}- \\
0.4335 * *\end{array}$ & -0.2050 & 0.0050 & $-0.2917 *$ & -0.0965 & -0.0953 \\
\hline & $\mathrm{P}$ & & & & & & & \begin{tabular}{|l|}
-0.1370 \\
\end{tabular} & \begin{tabular}{|l|}
0.0734 \\
\end{tabular} & -0.2465 & $-0.3474 *$ & -0.1749 & 0.0011 & \begin{tabular}{|l|}
-0.2538 \\
\end{tabular} & -0.0400 & -0.0399 \\
\hline \multirow{2}{*}{ Ear length } & G & & & & & & & & $\begin{array}{c}0.8904 * \\
*\end{array}$ & $0.8101^{*}$ & $0.6550 * *$ & $0.5492 * *$ & $\begin{array}{c}0.4185^{*} \\
*\end{array}$ & $\begin{array}{c}0.4883 * \\
*\end{array}$ & $0.4175^{* *}$ & $\begin{array}{c}0.4177 * \\
*\end{array}$ \\
\hline & $\mathrm{P}$ & & & & & & & & \begin{tabular}{|c|}
$0.5299 *$ \\
$*$
\end{tabular} & $0.4707 * *$ & $0.4203^{* *}$ & 0.2121 & $\begin{array}{c}0.2937^{*} \\
*\end{array}$ & $\begin{array}{c}0.2967 * \\
*\end{array}$ & 0.2699 & 0.2683 \\
\hline \multirow{2}{*}{$\begin{array}{c}\text { No. of } \\
\text { fingers/ear }\end{array}$} & G & & & & & & & & & $0.4574 * *$ & $0.5037 * *$ & $0.5066 * *$ & $0.3062 *$ & $\begin{array}{c}0.5005^{*} \\
*\end{array}$ & $0.5841 * *$ & $\begin{array}{c}0.5836^{*} \\
*\end{array}$ \\
\hline & $\mathrm{P}$ & & & & & & & & & $0.3656^{*}$ & $0.4263^{* *}$ & $0.4507 * *$ & 0.2840 & $\begin{array}{c}0.4602 * \\
*\end{array}$ & $0.5333 * *$ & 0.5326 \\
\hline \multirow{2}{*}{$\begin{array}{l}\text { Finger } \\
\text { length }\end{array}$} & G & & & & & & & & & & $0.7900 * *$ & $0.3841 * *$ & $\begin{array}{c}0.4222 * \\
*\end{array}$ & $\begin{array}{c}0.4173 * \\
*\end{array}$ & $0.3453^{*}$ & $0.3450 *$ \\
\hline & $\mathrm{P}$ & & & & & & & & & & $0.7491 * *$ & $0.2834 * *$ & $\begin{array}{c}0.3918^{*} \\
*\end{array}$ & $0.3566^{*}$ & $0.3024 *$ & $0.3019^{*}$ \\
\hline \multirow{2}{*}{$\begin{array}{l}\text { Finger } \\
\text { width }\end{array}$} & G & & & & & & & & & & & $0.5431 * *$ & $\begin{array}{c}0.4927^{*} \\
*\end{array}$ & $\begin{array}{c}0.6141 * \\
*\end{array}$ & $0.4850 * *$ & $\begin{array}{c}0.4843^{*} \\
*\end{array}$ \\
\hline & $\mathrm{P}$ & & & & & & & & & & & $0.4511 * *$ & $\begin{array}{c}0.4611^{*} \\
*\end{array}$ & $\begin{array}{c}0.5424 * \\
*\end{array}$ & $0.4247 * *$ & $\begin{array}{c}0.4244^{*} \\
*\end{array}$ \\
\hline \multirow{2}{*}{$\begin{array}{l}\text { No. of seeds } \\
\text { on main ear }\end{array}$} & $G$ & & & & & & & & & & & & 0.2152 & $\begin{array}{c}0.9049 * \\
*\end{array}$ & $0.9365 * *$ & $\begin{array}{c}0.9353^{*} \\
*\end{array}$ \\
\hline & $\mathrm{P}$ & & & & & & & & & & & & 0.1398 & $\begin{array}{c}0.8725^{*} \\
*\end{array}$ & $0.8421 * *$ & $\begin{array}{c}0.8426^{*} \\
*\end{array}$ \\
\hline
\end{tabular}




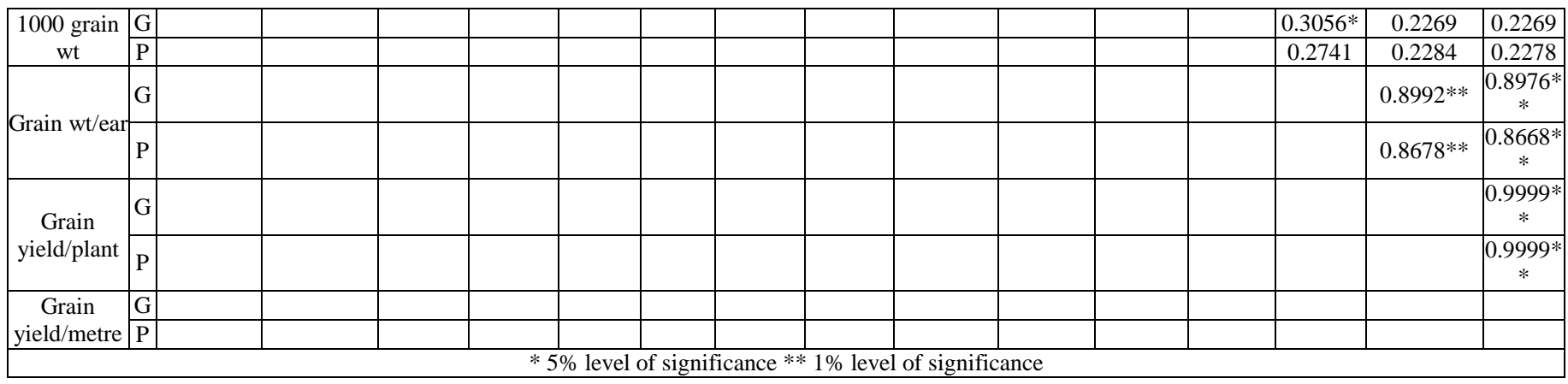

Table 3 (b): Genotypic and phenotypic correlation between various seed quality parameters in different Genotypes of Foxtail millet

\begin{tabular}{|c|c|c|c|c|c|c|c|c|c|c|c|c|c|}
\hline Characters & & \begin{tabular}{|c} 
Standard \\
germinati \\
on \%
\end{tabular} & $\begin{array}{c}\text { Germination } \\
\text { energy }\end{array}$ & $\begin{array}{l}\text { Mean daily } \\
\text { germination }\end{array}$ & $\begin{array}{c}\text { Speed of } \\
\text { germination }\end{array}$ & $\begin{array}{l}\text { Root } \\
\text { length }\end{array}$ & $\begin{array}{l}\text { Shoot } \\
\text { length }\end{array}$ & $\begin{array}{c}\text { Seedling } \\
\text { length }\end{array}$ & \begin{tabular}{|c|} 
Seedling \\
Fresh \\
weight
\end{tabular} & \begin{tabular}{|c|} 
Seedling \\
dry \\
weight
\end{tabular} & \begin{tabular}{|c|}
1000 \\
Seed \\
weight
\end{tabular} & $\begin{array}{c}\text { Vigour } \\
\text { Index II }\end{array}$ & $\begin{array}{l}\text { Vigour } \\
\text { Index I }\end{array}$ \\
\hline & & 1 & 2 & 3 & 4 & 5 & 6 & 7 & 8 & 9 & 10 & 11 & 12 \\
\hline \multirow{2}{*}{\begin{tabular}{c|c} 
Standard \\
germination $\%$
\end{tabular}} & & & $0.9867 * *$ & $1.000^{\text {*** }}$ & $0.9982 * *$ & $0.5620 * *$ & 0.1872 & $0.4298 * *$ & $0.6491 * *$ & $0.5122 * *$ & $0.3296^{*}$ & $0.8149 * *$ & $0.8969 * *$ \\
\hline & & & $0.9821 * *$ & $0.9999 * *$ & $0.9973 * *$ & $0.4631 * *$ & 0.1635 & $0.3508^{*}$ & $0.5771 * *$ & $0.4474 * *$ & 0.3097* & $0.7627 * *$ & 0.8778 *** \\
\hline \multirow{2}{*}{$\begin{array}{l}\text { Germination } \\
\text { energy }\end{array}$} & $\mathrm{G}$ & & & $0.9867 * *$ & $0.9947 * *$ & $0.5813 * *$ & 0.2015 & $0.4498 * *$ & $0.6332 * *$ & $0.4853 * *$ & $0.3333 *$ & $0.7904 * *$ & $0.9038 * *$ \\
\hline & $\mathrm{P}$ & & & $0.9821^{* *}$ & $0.9918^{* *}$ & $0.4749 * *$ & 0.1758 & $0.3651 *$ & $0.5630^{* *}$ & $0.4237 * *$ & $0.3153^{*}$ & $0.7363^{* *}$ & $0.8822 * *$ \\
\hline \multirow{2}{*}{$\begin{array}{l}\text { Mean daily } \\
\text { germination }\end{array}$} & $\mathrm{G}$ & & & & $0.9982 * *$ & $0.5620 * *$ & 0.1872 & $0.4298 * *$ & $0.6491 * *$ & $0.5122 * *$ & $0.3296 *$ & $0.8149 * *$ & $0.8969 * *$ \\
\hline & $\mathrm{P}$ & & & & $0.9973 * *$ & $0.4631 * *$ & 0.1635 & $0.3508 *$ & $0.5771^{* *}$ & $0.4474 * *$ & $0.3097 *$ & $0.7627 * *$ & $0.8778 * *$ \\
\hline \multirow{2}{*}{\begin{tabular}{c|c} 
Speed of \\
germination
\end{tabular}} & $\mathrm{G}$ & & & & & $0.5736 * *$ & 0.1928 & $0.4398 * *$ & $0.6431 * *$ & $0.5028 * *$ & $0.3271^{*}$ & $0.8090 * *$ & $0.9035 * *$ \\
\hline & $\mathrm{P}$ & & & & & $0.4675 * *$ & 0.1671 & $0.3555^{*}$ & $0.5710^{* *}$ & $0.4432 * *$ & $0.3084 *$ & $0.7586^{* *}$ & $0.8814 * *$ \\
\hline \multirow{2}{*}{ Root length } & $\mathrm{G}$ & & & & & & 0.3587* & $0.7819 * *$ & $0.6483 * *$ & $0.6806 * *$ & $0.3523^{*}$ & $0.6912 * *$ & $0.6799 * *$ \\
\hline & $\mathrm{P}$ & & & & & & $0.4236^{* * *}$ & $0.8039 * *$ & $0.5176^{* *}$ & $0.4843^{* *}$ & 0.2638 & $0.5187 * *$ & $0.5982 * *$ \\
\hline \multirow{2}{*}{ Shoot length } & $\mathrm{G}$ & & & & & & & $0.8623 * *$ & $0.6081 * *$ & 0.0657 & $0.3334 *$ & -0.0356 & $0.4941 * *$ \\
\hline & $\mathrm{P}$ & & & & & & & $0.8793 * *$ & $0.5161 * *$ & 0.0942 & 0.2543 & -0.02590 & $0.4537 * *$ \\
\hline \multirow{2}{*}{ Seedling length } & $\mathrm{G}$ & & & & & & & & $0.7577 * *$ & $0.4130 * *$ & $0.4137 * *$ & $0.3987 * *$ & $0.6987 * *$ \\
\hline & $\mathrm{P}$ & & & & & & & & $0.6110 * *$ & $0.3165^{*}$ & $0.3057 *$ & $0.2897 *$ & $0.6124 * *$ \\
\hline \multirow{2}{*}{$\begin{array}{c}\text { Seedling Fresh } \\
\text { weight }\end{array}$} & $\mathrm{G}$ & & & & & & & & & $0.5619 * *$ & $0.5422 * *$ & $0.5430 * *$ & $0.7346^{* *}$ \\
\hline & $\mathrm{P}$ & & & & & & & & & $0.4734 * *$ & $0.4531 * *$ & $0.4587 * *$ & $0.6578 * *$ \\
\hline \multirow{2}{*}{$\begin{array}{c}\text { Seedling dry } \\
\text { weight }\end{array}$} & $\mathrm{G}$ & & & & & & & & & & $0.3301 *$ & $0.8363 * *$ & $0.4384 * *$ \\
\hline & $\mathrm{P}$ & & & & & & & & & & $0.3000^{*}$ & $0.8284 * *$ & $0.3592 *$ \\
\hline \multirow{2}{*}{$\begin{array}{c}1000 \text { Seed } \\
\text { weight }\end{array}$} & $\mathrm{G}$ & & & & & & & & & & & 0.2747 & $0.3605^{*}$ \\
\hline & $\mathrm{P}$ & & & & & & & & & & & 0.2625 & $0.3310^{*}$ \\
\hline \multirow{2}{*}{\multicolumn{2}{|c|}{ Vigour Index II }} & & & & & & & & & & & & $0.7063 * *$ \\
\hline & & & & & & & & & & & & & $0.6349 * *$ \\
\hline \multirow{2}{*}{\multicolumn{2}{|c|}{ Vigour Index I $\mid \frac{\mathrm{G}}{\mathrm{P}}$}} & & & & & & & & & & & & \\
\hline & & & & & & & & & & & & & \\
\hline
\end{tabular}

**1\% level of significance

$* 5 \%$ level of significance

\section{References}

1. Baghel BRS, Maloo SR. Genetic variability in proso millet (Panicum miliaceum). Indian $\mathrm{J}$ of Agric. Sci 2002;72(7):431-432.

2. Chang K. Archeology of ancient China. Science 1968;162:519-526.

3. Giriraj K, Goud JV. Studies on Genetic Diversity in Sorghum 1981. agris.fao.org

4. Giriraj K, Goud JV. Association of yield components and developmental traits in grain sorghum. Indian $\mathbf{J}$ agric. Sci 1983;53(1):5-8.

5. Gomez KA, Gomez AA. Statistical procedures for Agricultural Research. John Wiley and Sons Inc., New York 1980, 641.

6. ISTA. International rules for seed testing. Seed Sci. \& Technol 2008;26:234-35.

7. Jain SK, Patel PR, Elangovan M. Variation and association among fodder yield and other traits in germplasm of forage sorghum (Sorghum bicolor (L.) Moench). Indian Journal of Plant Genetic Resources 2011;24(3):327-331.

8. John K. Estimates of genetic parameters and character association in finger millet (Eleusine coracana Gaerten).
Agric. Sci. Digest 2007;27(2):95-98.

9. Joshi HC, Katoch KC. Nutritive values of millets- A comparison with cereals and Pseudocereals. Himalayan Research and Development 1990;9(1-2):26-28.

10. Li H, Meng WJ, Liu TM. Problems in the breeding of millet (Setaria italia (L.) Beauv.). J Am. Soc. Agron 1935;27:426-438.

11. Marathee JP. Advances in small millets. New Delhi, India 1993,159-178.

12. Marcon AE. Wheat streak mosaic virus resistance in foxtail millet, Setaria italic, L. Beauv., and factors related to resistance. M.Sc. Thesis, Univ. Nebraska, Lincoln 1994.

13. Pant SC, Singh P. Genetic variability in Indian mustard. Agric. Sci. Dig 2001;21(1):28-30.

14. Patil K. Studies on seed quality parameters of different generations of finger millet (Eleusine coracana) M.Sc (Agri.) Thesis. Univ. G.B.P.U.A\&T. Pantnagar 2007.

15. Schery RW. Plants for man. $2^{\text {nd }}$ ed. Prentice-Hall, Englewood Cliffs, NJ 1972, 440-442.

16. Singh VV, Singh Maharaj, Chauhan JS, Kumar Sunil. Development and evaluation of full sib progenies of Indian Mustard (Brassica juncea (L.) for moisture stress 
conditions. Indian Journal of Genetics and Plant Breeding 2011;71(1):78-81.

17. Sonnad KS, Shanthakumar G, Salimath PM. Genetic variability and character association studies in white ragi (E. coracana Gaertn). Karnataka J Agri. Sci 2008;21(4):572-575.

18. Yadav SK, Dhankhar BS. Correlation studies between various field parameters and seed quality traits in Okra cv. Varsha Uphar. Seed Research 2001;29(1):84-88. 